\title{
Social hierarchy of pain and its connection to the memory of previously suffered pain
}

This article was published in the following Dove Press journal: Journal of Pain Research

\section{Lourdes Biedma-Velázquez María Isabel García- \\ Rodríguez Rafael Serrano-del-Rosal}

Institute for Advanced Social Studies, Spanish National Research Council (IESA/CSIC), Córdoba, Spain
Correspondence: Rafael Serrano-del-Rosal IESA/CSIC, C/Campo Santo de los Mártires, no 7, 14004 Córdoba, Spain $\mathrm{Tel}+34957760260$

Fax +34957760 I53

Email rserrano@iesa.csic.es
Background: Pain is a perception conditioned both by the painful experience and by each society's collective imagination. The general objective of the project which this work forms part of it was to discover what citizens think about different aspects of this complex experience. More precisely, this paper's objective is to get to know which is the worst pain that can be suffered according to Spaniards and what determines that hierarchy, bearing in mind that this work has chosen a broad definition of pain, including pains of different origins, namely, physical, psychological, and emotional pain.

Materials and methods: The data from the CIS 3137 study "Social perceptions of pain" have been used, which is a survey module designed by the Institute of Advanced Social Studies (IESA) of the Spanish National Research Council (CSIC). A hierarchical multiple factor analysis has been performed, using the SPSS statistical analysis software, where the dependent variable is the citizen's opinion on which is the worst pain that can be suffered, recoded according to the origin of pain (physical, psychological, and emotional pain). Sociodemographic variables and variables linked to the experience of pain have been included as independent variables.

Results and conclusion: Although the most frequent pains among Spanish citizens are those of a physical origin, especially those linked to musculoskeletal problems and pains of an orofacial origin, when they are asked about the worst pain a person can suffer, they do not mention this type of pain, but those of an emotional origin. It has also been possible to confirm that the pain that citizens refer to when asked about the worst pain that can be suffered, and, therefore, the hierarchy of pain held by Spanish citizens as a group, is conditioned, although not determined, by the pain that has previously been suffered - by one's own experience of pain.

Keywords: pain, social perception, physical pain, psychological pain, emotional pain, experience of pain

\section{Introduction}

Pain, as a multidimensional phenomenon, must be tackled from different perspectives, if it is to be accounted for it in all its complexity. Today, it is assumed that pain, apart from being an unquestionable physical and anatomical element, ${ }^{1}$ cannot be completely understood if its cultural and social elements are not taken into account, ${ }^{2}$ which lead to pain being interpreted, perceived, and modeled differently in different cultures, societies, and social groups. This is why pain must be understood as a multifaceted, socially constructed phenomenon, where psychological elements (those linked to the way pain is faced, as well as its adjustment) intervene, together with educational, cultural, and sociological elements (which involve the perception and 
meaning that an individual attributes to pain), apart from the obvious biological elements (which determine, at least in part, its location, duration, and intensity). ${ }^{3-5}$ Only from this perspective, has it been possible to develop and assume concepts such as "Total Pain," "6 wich take into account and defend this multifaceted nature.

In this paper, our conceptual base is the International Association for the Study of Pain (IASP)' $\mathrm{s}^{7}$ definition of pain, which is defined as follows: "Pain is an unpleasant sensory and emotional experience associated with actual or potential tissue damage or described in terms of such damage." This view of pain as a subjective (individual) and intersubjective (since it is socially learned and shared) event is the base which makes it both possible and advisable to be interpreted as something beyond an objective fact, ie, as the expression of a social context. ${ }^{8-10}$

The complexity of studying pain, partially caused by its multidimensionality, makes it appropriate and necessary to properly limit its study. More precisely, in this work, we are going to focus on three elements: the classification of pain, the memory of a painful event, and its social hierarchization.

As regards the first elements, we must assume that there is no single classification of pain in the literature, not even a group of classifications that has been generally accepted. Each author, each research, uses the one that is closer and most appropriate to its interests of their research (according to the pain's location, duration, intensity, origin, etc), which is yet another indicator of the complexity of the phenomenon we are analyzing. In our study, we have chosen the classification of pain according to its origin, ${ }^{11}$ which suits our research's objectives. Thus, we have broken down pain into physical pain (bone pain, headache, stomachache, etc), psychological pain (caused by anxiety, tiredness, angst, etc), and emotional pain (heartbreak, grief, betrayal, etc). This classification focuses on the origin of pain, although it assumes that pain is not different because of it, ie, it does not differentiate between pain and suffering, as other authors do, because, as already proven, the brain activates the same areas when there is physical or emotional pain, ${ }^{12}$ which does not mean that on a social level they are perceived as similar pains, giving them specific meanings.

As for the second element, the memory of a painful event, we must bear in mind that the narrative of a painful event makes it necessary for us to remember it, which will be easier if that event had emotional connotations (which is usually the case with other traumatic or adverse situations) than if it was a trivial event. ${ }^{13}$ However, our memory is "tricky," as our brain believes, invents, and interprets in order to make the past coherent. ${ }^{14}$ When we remember something, our memory also remembers the general meaning of the experience, which has been called the memory of the painful experience, although it tends to forget the details, ${ }^{14}$ the memory of the painful event. ${ }^{15}$ Thus, we remember the essence of what happened, but it is difficult to evoke the intensity of the pain, the pain in its most physical dimension. Pain and memory are closely connected, as some studies on neuronal processes are showing, like those studying long-term synaptic depression ${ }^{16}$ and its connection to memory, or other studies on chronic pain and its connection with the limbic system, which predispose toward perpetuating pain, due to what is known as "the memory of pain."17

In more sociological terms, the meaning that has subsequently been given to that memory of pain is added to it. If a meaning is applied to that pain (a warning about something that was not working properly in our organism, a transient or natural pain in a given process, it prepared us for something else, etc), the narration we will make about it will be very different to if it does not have a narrative meaning. Moreover, building a discourse on a sensation is very complex, and it requires having complex cognitive and linguistic abilities. In that narration, what the cultural and social context of the person considers "legitimate" or not is very important too, as regards a specific type of pain, whose proxy may be found in the type of words and expressions used to define each pain in a given context. In this respect, pain is socially constructed and ritualized, ${ }^{9}$ which accounts for the fact that its public exposure is different and is influenced by the legitimacy of pain, what is considered to be expected or not about pain.

As regards the third and last element, we must point out that there is a cultural and social view that organizes pain in a hierarchy, according to its type and/or intensity, according to its nature, according to whether it has a "meaning" or not, which, in general, constructs an unwritten cognitive framework that enables us to discover which pains are more or less bearable, more or less intense, more or less legitimate. Within this framework, not only does the type of pain have an influence, depending on the illness or pathology, but also the patients' own role and how they show their pain do. It is not only that there are pains which are more legitimate than others but there are also patients with more social legitimacy. Accordingly, a child's pain is not perceived in the same way as that of an elderly person, a man, or a woman.

Given this conceptual and analytical framework, the objective of this study is to know which is the worst pain 
that can be suffered according to Spanish citizens and what influences that hierarchy.

\section{Materials and methods}

This paper's empirical base is the CIS 3137 survey on opinions and attitudes toward pain, carried out from June to July 2016. This is a general population survey, which was performed by means of a face-to-face questionnaire at citizens' homes, following a system of routes for selecting homes randomly. No ethics approval was necessary, per The National Committee on Health Research Ethics, as the study concerns surveys and no human biological material. Anonymity is always guaranteed. All participants are informed that their identity is treated anonymously in the investigation, and they are protected by Spanish legislation: Royal Decree-Law $5 / 2018$, of July 27 , on urgent measures for adaptation of Spanish Law to European Union regulations on data protection. Every data used have been correspondingly anonymized.

The population under study (the sampling universe) was the population living in Spain, over 18 years of age. A theoretical sample of 2,500 people was designed, and a final total of 2,464 individuals were surveyed. It was a random multistage sampling, stratified by clusters, taking into account gender and age quota, so that the sampling fits the proportionality of the general population living in Spain, assuming a sampling error of $\pm 2.0 \%$, with a $95 \%$ confidence level. The questionnaire was applied through computer-assisted personal interviewing at people's homes. The description of how the field work was carried out is available at: http:// www.cis.es/cis/opencms/EN/1_encuestas/ComoSeHacen/ pasosencuesta.html

Considering our objective for this research, the following analyses have been done: first of all, a classification of pain according to its origin has been established, breaking it down into three analytical groups: pain of physical origin, pain of psychological origin, and pain of emotional origin. Second, a bivariate analysis was performed between the variables of the worst pain that can be suffered and the worst pain that has been suffered (the most relevant for the individual), both variables grouped according to the previous classification. Third, a hierarchical segmentation analysis was performed to analyze which characteristics had a greater influence on the dependent variable's variation, ${ }^{18}$ which, in our case, is the worst pain that may be suffered, the independent or explicative variables being the main sociodemographic variables (gender, education level, employment situation, income, marital status) and variables having to do with their pain experience (the experienced pain considered as the most relevant, the duration of pain, its frequency, number of pains, etc). The hierarchical segmentation analysis' unusual feature is that it selects the variable with the most discriminant power first, ie, it statistically differentiates the response categories to a greater extent, these categories being the origin of new divisions and, therefore, certain variables (the first ones) condition the inclusion of the following variables (secondand third-level variables). All this allows us to create profiles with significant differences regarding the dependent variable, which are very explicative visually.

\section{Results}

As has been pointed out, first of all the pains suffered by citizens have been classified according to their origin. Table 1 shows the incidence of each of the pains mentioned by the respondents, either they have suffered them over the course of their lives or are suffering them at present. It also shows the one that they have mentioned as being the most relevant, the most significant in their personal history, whatever the reason. The questions included in the questionnaire may be found in Table $\mathrm{S} 1$.

The pains most often mentioned include bone or muscle pain, and headache, earache, eye pain, or toothache, which $66 \%$ of the population has suffered over the course of their lives. In both cases, these are the most persistent pains at present too, with $47 \%$ and $32 \%$ of the surveyed individuals suffering them at the moment, respectively. The pain caused by the death of a loved one is the third most commonly mentioned pain, suffered by $62 \%$ of the population, but only suffered by $5.8 \%$ at present. As may be seen, the population has an extensive experience of pain, with many different types of pain being mentioned in their personal experiences.

As far as the variable at hand is concerned, the most relevant pain is musculoskeletal pain, followed by the death of a loved one and, in the third position, orofacial pain, the three of them constituting $68 \%$ of the painful experiences. In this way, physical pain, the pain whose origin is linked to a body part, is the most often mentioned, being the most frequent and the one that is most often suffered at present.

Once the pain suffered by the Spanish population was identified, its classification was performed, grouping the type of pain according to its origin. This classification is summarized in Table 2.

With this classification, the data presented in Figure 1 for the variable "most relevant pain ever suffered" are obtained. It may be seen that the first one is the pain of physical origin, which is reported by almost $60 \%$ of the population, followed by the pain of emotional origin, which 
Table I Experience of pain in respondents' life, at present, and the most relevant pain ever experienced

\begin{tabular}{|l|l|l|l|}
\hline Experience of pain & $\begin{array}{l}\text { Over the course } \\
\text { of their life }\end{array}$ & $\begin{array}{l}\text { Most } \\
\text { relevant pain }^{\text {At }}\end{array}$ \\
\hline Bone or muscle pain & $66.9 \%$ & $47.5 \%$ & $30.6 \%$ \\
\hline Headache, earache, eye pain, or toothache & $66.6 \%$ & $32.2 \%$ & $17.8 \%$ \\
\hline Stomachache, digestive distress, liver, or kidney pain & $42.2 \%$ & $12.6 \%$ & $7.7 \%$ \\
\hline Pain caused by breathing problems & $13.7 \%$ & $4.5 \%$ & $2.1 \%$ \\
\hline Pain caused by anxiety, depression, or stress & $28.7 \%$ & $9.4 \%$ & $4.8 \%$ \\
\hline Pain caused by tiredness or for no apparent reason & $21.5 \%$ & $6.9 \%$ & $1.1 \%$ \\
\hline Pain caused by a continuing feeling of anguish & $12.5 \%$ & $3.8 \%$ & $0.6 \%$ \\
\hline Pain caused by heartbreak or breakup & $17.7 \%$ & $2.0 \%$ & $2.3 \%$ \\
\hline Pain caused by the death of a loved one & $62.0 \%$ & $5.8 \%$ & $20.0 \%$ \\
\hline Pain caused by an important betrayal or deception & $19.2 \%$ & $1.4 \%$ & $1.2 \%$ \\
\hline Pain caused by serious illness of a loved one & $42.2 \%$ & $4.6 \%$ & $4.0 \%$ \\
\hline Other pains considered important & $2.6 \%$ & $1.2 \%$ & $3.0 \%$ \\
\hline (Do not read) No pain & $5.4 \%$ & $22.9 \%$ & $4.3 \%$ \\
\hline No answer/do not remember & $0.7 \%$ & $1.0 \%$ & $0.5 \%$ \\
\hline
\end{tabular}

Notes: aMultiple choice: the percentage shown corresponds to the people who mention a particular kind of pain, so it may be over $100 \%$, as a person may suffer more than one type of pain over the course of their life and at present. That is not the case for the most relevant pain ever suffered, as respondents are asked to choose only one. Data from Centro de Investigaciones Sociológicas. ${ }^{33}$

Table 2 Classification of pain according to its origin

\begin{tabular}{|l|l|l|}
\hline Pain according to its origin & Most relevant pain \\
\hline Physical pain & $\begin{array}{l}\text { This pain derives from an organic injury or } \\
\text { dysfunction, ie, a tissue injury or dysfunction, } \\
\text { be it real or perceived. It may be nociceptive or } \\
\text { neuropathic. In our case, questions q7, q9, and q10 } \\
\text { deal with pains in the body. }\end{array}$ & $\begin{array}{l}\text { - Bone or muscle pain } \\
\text { - Headache, earache, eye pain, or toothache } \\
\text { - Stomachache, digestive distress, liver, or kidney pain } \\
\text { - Pain caused by breathing problems } \\
\text { - Reproductive system and labor pain } \\
\text { - Pain caused by severe or chronic diseases } \\
\text { - Pain caused by surgery, aggressions, accidents, and } \\
\text { unexpected pain }\end{array}$ \\
\hline Psychological pain & $\begin{array}{l}\text { Pain whose origin is either a mental illness or a } \\
\text { dysfunction, such as anxiety, depression, or stress, or } \\
\text { a feeling of unease and distress or tiredness for no } \\
\text { apparent reason. }\end{array}$ & $\begin{array}{l}\text { - Pain caused by anxiety, depression, or stress } \\
\text { - Pain caused by tiredness for no apparent reason } \\
\text { - Pain caused by a continuing feeling of anguish }\end{array}$ \\
\hline Emotional pain & $\begin{array}{l}\text { caused by incomprehension, by the death of a loved } \\
\text { one, injustice, depression, and loneliness (Sánchez } \\
\text { This pain appears in different forms, through physical } \\
\text { symptoms of pain and through psychosocial behaviors } \\
\text { of suffering. }\end{array}$ & $\begin{array}{l}\text { - Pain caused by heartbreak or breakup } \\
\text { - Pain caused by the death of a loved one } \\
\text { - Pain caused by an important betrayal or deception } \\
\text { - Pain caused by serious illness of a loved one } \\
\text { - Pain caused by being away from and worried about } \\
\text { children and loved ones }\end{array}$ \\
\hline
\end{tabular}

Notes: According to its origin, pain may be classified into physical pain, psychological pain, and moral or spiritual pain, which we have called emotional pain. Data from Centro de Investigaciones Sociológicas. ${ }^{33}$

is the most relevant one for $26 \%$ of the surveyed population; finally, the pain of psychological origin is reported by $6 \%$ of the population. Also, $6 \%$ of citizens report either not having suffered any pain or that they consider that none of the pains they have experienced are relevant, so they do not highlight any pain.
The following analysis variable has been the citizens' opinion on which is the worst pain that may be suffered. This belief means that citizens have implicitly created a hierarchy of pain, and they state which one is the worst one for them, which one involves a higher degree of suffering. As may be seen in Figure 2, the worst pain that may be suf- 


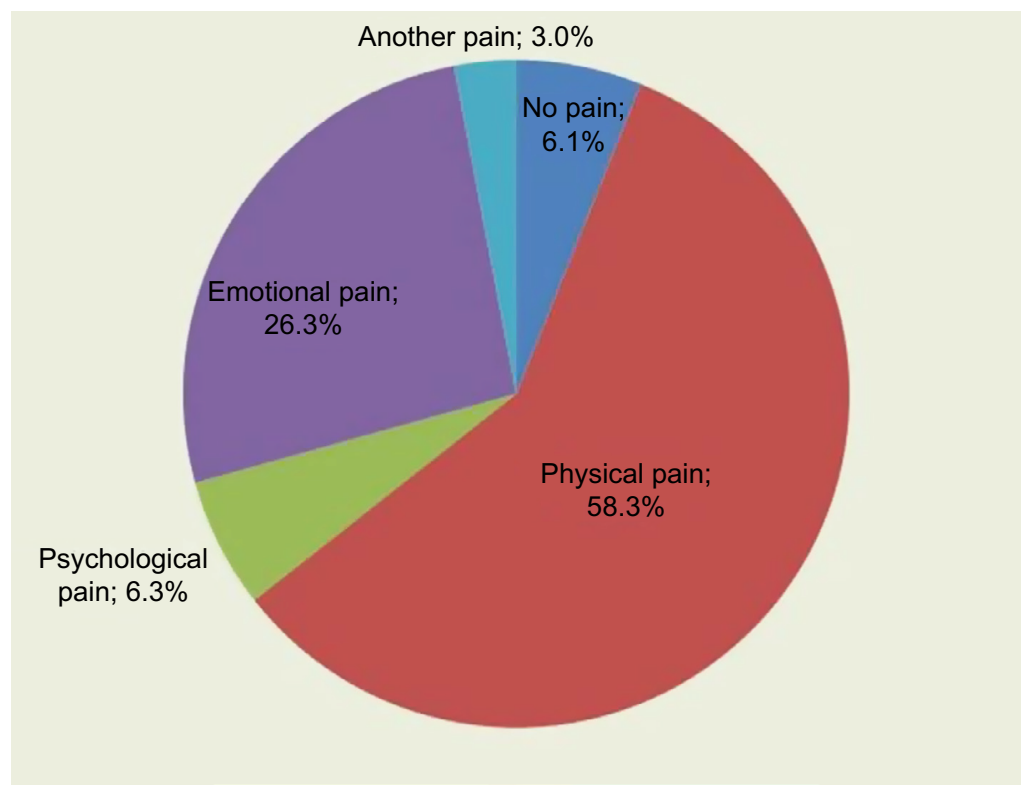

Figure I Percentage of most relevant pain broken down by types of pain according to their origin. Note: Data from Centro de Investigaciones Sociológicas. ${ }^{33}$

fered, according to the people surveyed, is emotional pain, as stated by $47.8 \%$ of them (see total column in Figure 2), the pain caused by the death of a loved one being especially significant. In a second place, there is the pain of physical origin, and, in the last place and with a low prevalence, the pain of psychological origin. The latter is proven not to be conceived of as an especially relevant pain for citizens, a minority of whom, in general, has suffered it.

Not everyone stated that the same kind of pain is the worst one that may be suffered (since their starting point is their own hierarchy of pain). Nevertheless, at the aggregate level, there are significant differences: men tend to consider physical pain as the worst one that may be suffered, whereas women are more likely to think that the worst pain that may be suffered is emotional pain. Age is also a variable affecting the hierarchy given to pain, as older people are the ones who most often consider emotional pain as the worst possible pain. Lastly, it bears mentioning that physical pain is less important when compared with psychological and emotional pain among university graduates (Table 3 ).

The connection made by the respondents between the pain they mention as the worst one that may be suffered and the pain actually experienced, considered as the most relevant in their personal experience, may also be observed in this figure. Thus, it may be seen that when a person has stated that their main pain has been of an emotional origin, it is mentioned as the worst possible pain to be suffered by
$73.8 \%$ of the respondents, 26 percentage points above the general level. If the most relevant experience of pain has been stated to be a physical pain, this type of pain increases by 11.4 percentage points the percentage of people selecting it as the worst pain that may be suffered compared with the total, and if psychological pain has been mentioned as the most relevant pain ever suffered, this type of pain increases by 17 percentage points when it comes to imagining the worst possible pain. Therefore, in general, an association of interest may be pointed out between the most relevant pain suffered by a person and their vision of the worst pain that may be suffered, the experience of pain thus somehow conditioning the imaginary on pain, even though the case where this association is more powerful is the case of emotional pain.

Once we confirmed the bivariate association between the experience of pain and the hierarchization of the worst possible pain as important but not definitive, we tried to go a little deeper and to discover if these differences are statistically significant through a multiple factor analysis. This is why a hierarchical segmentation analysis was made, the dependent variable being the worst pain that the person believes that may be suffered, and the independent variables being the sociodemographic variables and those linked to their experience of pain.

The results of this analysis may be graphically observed in the tree in Figure 3. As may be seen, the most discriminant variable, the one causing the first division from the dependent 


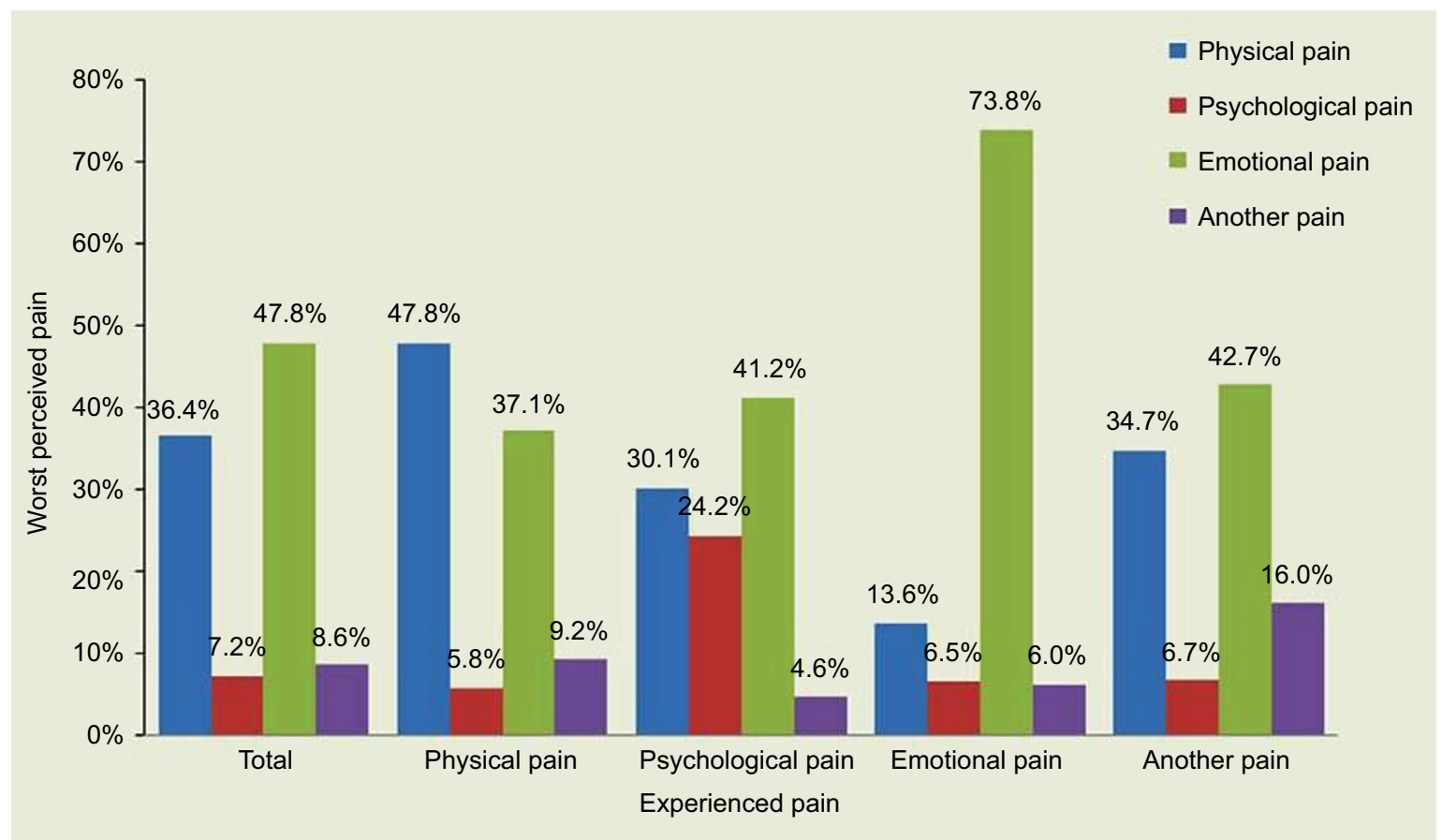

Figure 2 Worst pain that may be suffered (total and according to the most relevant pain ever experienced). Note: Data from Centro de Investigaciones Sociológicas. ${ }^{33}$

Table 3 Worst pain that may be suffered according to the main sociodemographic variables

\begin{tabular}{|l|l|l|l|l|l|}
\hline Worst perceived pain & $\begin{array}{l}\text { Physical } \\
\text { pain }\end{array}$ & $\begin{array}{l}\text { Psychological } \\
\text { pain }\end{array}$ & $\begin{array}{l}\text { Emotional } \\
\text { pain }\end{array}$ & $\begin{array}{l}\text { Another } \\
\text { pain }\end{array}$ & $\begin{array}{l}\text { Pearson's } \\
\text { chi-square }\end{array}$ \\
\hline Men & $52.5 \%$ & $47.7 \%$ & $43.3 \%$ & $59.8 \%$ & 0.000 \\
\hline Women & $47.5 \%$ & $52.3 \%$ & $56.7 \%$ & $40.2 \%$ & \\
\hline $18-29$ years & $15.0 \%$ & $20.5 \%$ & $16.7 \%$ & $9.1 \%$ & 0.000 \\
\hline $30-45$ years & $31.4 \%$ & $38.6 \%$ & $28.7 \%$ & $26.3 \%$ \\
\hline $46-65$ years & $32.9 \%$ & $31.3 \%$ & $32.5 \%$ & $35.9 \%$ & $28.7 \%$ \\
\hline $66+$ years & $20.7 \%$ & $9.7 \%$ & $22.1 \%$ & $8.1 \%$ \\
\hline No education & $7.4 \%$ & $2.3 \%$ & $7.7 \%$ & $19.6 \%$ \\
\hline Primary education & $17.7 \%$ & $9.7 \%$ & $23.6 \%$ & $20.6 \%$ \\
\hline Secondary education & $24.7 \%$ & $21.6 \%$ & $13.1 \%$ & $13.5 \%$ & $13.9 \%$ \\
\hline General certificate of education & $12.4 \%$ & $22.7 \%$ & $15.4 \%$ & $12.4 \%$ \\
\hline Vocational education and training & $17.6 \%$ & $29.5 \%$ & $23.2 \%$ & $23.9 \%$ \\
\hline University degree & $19.4 \%$ & & & 0.009 \\
\hline
\end{tabular}

Note: Data from Centro de Investigaciones Sociológicas. ${ }^{33}$

variable, is the already experienced pain that was mentioned as the most relevant. Thus, the pain of emotional origin is perceived as the worst pain that may be suffered in general (being the modal category), but if the person has previously suffered it, its incidence increases significantly (26 percentage points, as may be seen in Node 4), mainly among women with a low level of education, who mention this type of pain 8 out of 10 times, more precisely, $38.5 \%$ over the general percentage (Node 13). The pain of psychological origin is also influenced by the experienced pain, which increases by $24.2 \%$ among those who report it (17 points above), but since those who report it are few (6.3\% of the total), it does not provide a second-level discrimination (Node 2). Lastly, it is also interesting to observe that the pain of physical origin is mentioned as the worst pain that may be suffered by the people who have said that it is the most relevant pain 


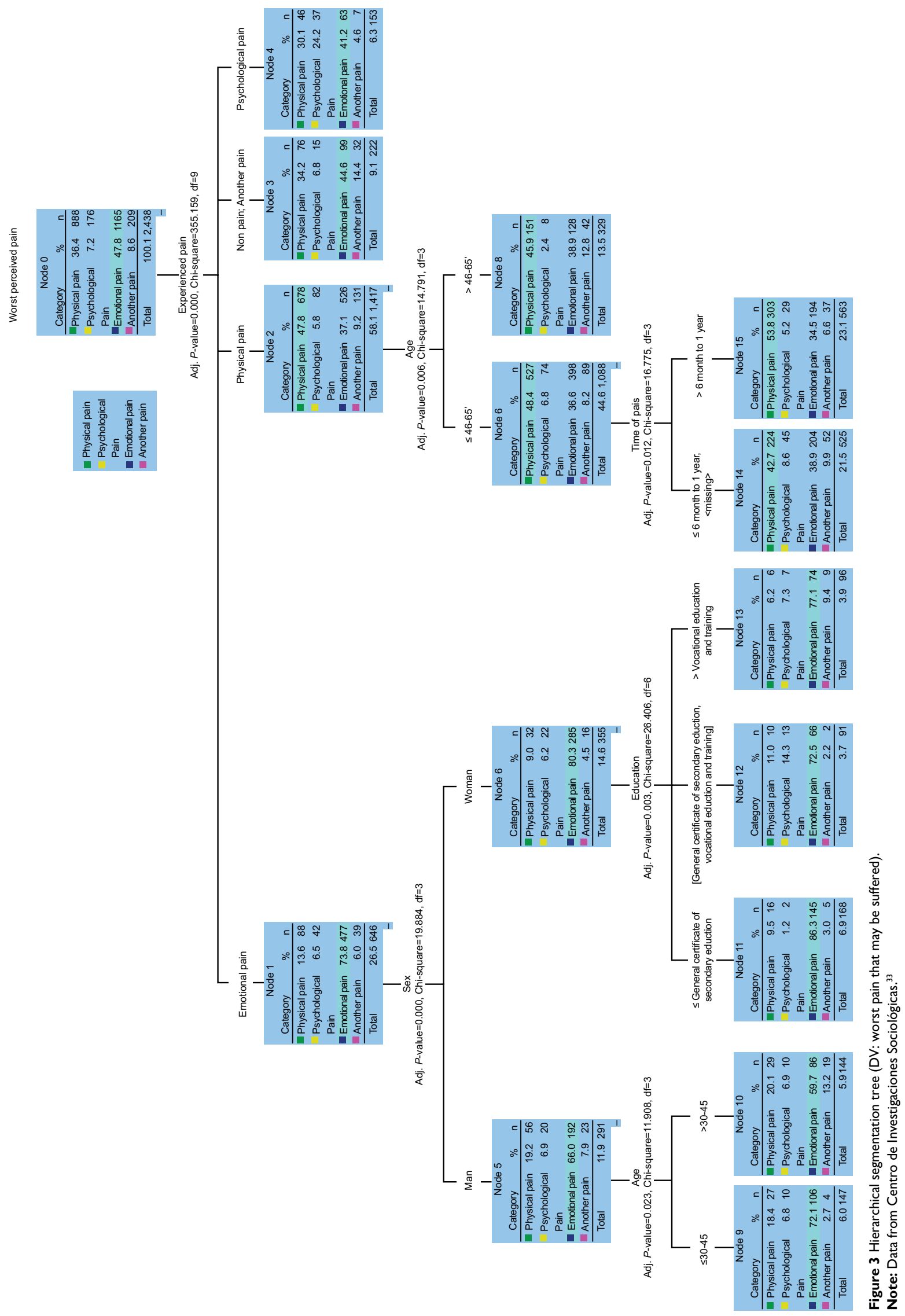


in their personal history, increasing by $>11$ points (Node 1 ), especially if they are relatively young people $(<46$ years old) who have been suffering this pain for $>1$ year, ie, people with chronic pain. Among them, mentioning physical pain as the worst pain that may be suffered represents $53.8 \%, 17.4$ percentage points above the general data (Node 10).

In short, it may be pointed out that, even if there is some consensus on how painful emotional pain is, the experience of pain modulated this perception, accentuating it when it has been suffered and minimizing it when not.

\section{Discussion}

Pain is a subjective life experience, but also common to everyone and, thus, intersubjective in its meaning and definition, which means that, even if no one is able to experience another person's pain, people are able to empathize and understand other people's suffering. The intersubjective nature of the experienced pain is what makes empathy possible, so this is created on the basis of a social construction of pain that is socially defined and hierarchized, so, in a collective way, it is assumed that not only is there a gradation among the pains that are recognized but also those that are not recognized or contradict that hierarchy do not exist or are socially illegitimate. All of this is why it is very important to study pain, among other reasons, because the beliefs and expectations on pain may modify the threshold of pain, ${ }^{19,20}$ health policies linked to pain, ${ }^{21}$ as well as the way pain is conceived and alleviated. .2-24 $^{2}$

In this regard, it is interesting to analyze the classification of pain according to its origin, which has led us to identify three main types of pain that most people are able to comprehend: pain of physical origin, pain of psychological origin, and pain of emotional origin. This division, simple as it may seem, has proven to be greatly useful for analyzing the differences found in the social legitimacy of pain.

In this sense, it is necessary to link the concept of social legitimacy of pain to Bourdieu's concept of symbolic capital. ${ }^{25}$ From this perspective, pain acquires part of its meaning through the symbolic capital that is able to provoke in others (pity, admiration, sorrow, rejection, etc). Pain's symbolic capital makes it be perceived as worthy of compassion, or even praise, or, on the contrary, as something to be avoided, which is considered fake or at least questionable. Thus, every difference that is accepted as socially legitimate acts as symbolic capital. ${ }^{25}$

For its part, this paper intends to bring together pain's social legitimacy and the hierarchy of pain formed by indi- viduals. Social hierarchy is the order that determines the connections among the analyzed elements, which may be a social or symbolic order, or an order of interaction. At the symbolic level, a different value (either positive or negative if compared with the other types) is attributed to an element, in this case, to a specific type of pain. Because this symbolic order does not occur in an individual but in a social way, and because it establishes higher and lower social levels and hierarchical positions, a social structure of pain occurs, from the sociological point of view.

Following that premise, we have confirmed that even if physical pain is the most relevant among the pains experienced by most citizens, followed by emotional pain and, lastly, psychological pain; when moving from the most relevant pain that has been experienced to the worst pain that may be imagined, respondents do not follow the same order, thus confirming the existence of a collective imagination on pain and its hierarchy, which does not necessarily correspond to the citizen's prevalence or experience of pain.

However, it has also been possible to confirm that the pain citizens consider to be the worst possible and, as a result, the hierarchy of pain that citizens as a whole maintain, is significantly conditioned, although it is not always decisive, by the pain that has already been suffered, by one's own experience of pain. This accounts for the fact that the hierarchy of pain is not the same when asked about the most relevant pain ever suffered and the worst pain that may be imagined. Also, when a person identifies pain as the most relevant in their experience, the chance of them considering it the worst possible pain increases. Therefore, emotional pain is mentioned as the worst pain possible by Spanish citizens, although, in general, it has been experienced as the most relevant by fewer people than that of physical origin.

It has been noted that the social legitimacy of pain is not the same according to the type of pain suffered and to who is suffering it. Therefore, apart from a socially constructed hierarchy of pain, we have found that the experienced pain is an essential element in the experience of pain, which makes its memory linger in the sufferer's memory, conditioning its perception of legitimacy. Furthermore, certain social characteristics of the person also have an influence, such as the fact of being a woman with a low level of education, which is the reflection of the profile of people who suffer emotional pain. Sadly, pain and women go together, and, if the characteristics reflecting a low social status are added, this connection is more frequent. Women, mainly with a low level of education, as mentioned above, are the people who mention emotional 
pain as the worst one that may be suffered, because, in addition, they remember it, they have experienced it.

In turn, emotional pain holds a strong position on the collective imagination, as a pitiful pain, socially legitimated and recognized as such. It is not the case for psychological pain, which is only recognized by the people who have suffered it and considered it as the most relevant pain they have experienced. It is a socially invisible and hardly legitimized pain, which sometimes is difficult to assume as such, as another type of pain, which is perceived as a clear influence of the social stigma often suffered by patients suffering from illnesses of a mental nature. ${ }^{26,27}$

Therefore, the "social prejudice" against certain illnesses may be found in the belief that these diseases are the responsibility of the individual, that they are an illegitimate deviation and, therefore, morally reprehensible. ${ }^{28}$ Thus, the pain itself, as well as the person who suffers it, is element with its own legitimacy, due to its social class, gender, etc, which has an influence on the disease's legitimacy. The way in which people interpret their own pain and other people's pain influences the way in which people in pain end up behaving. One's behavior is shaped in accordance with one's expectations and how one considers that others interpret their pain, the social pain being just another element for diagnosis, which will have influence in the modulation of pain, and on how it is confronted and expressed.

Humans are social beings who develop and live with a series of values and cultural norms, in contact with other humans, which affects the way we see and perceive the world. Although pain is a universal phenomenon, there are important differences in the perception, expression, and tolerance of pain, due to different psychological and social characteristics. ${ }^{29}$ It seems obvious that there is a social component accounting for part of how pain is experienced by the population, as it is not the same to suffer a pain other people legitimate, a pain that causes empathy and other people's understanding, and to suffer a pain lacking all of this. While neuroscience tells us that the neuronal mechanisms underlying pain are similar either in the case of physical and emotional pain, ${ }^{30-32}$ we find differences in the social study of pain, in its sociology. This is why we consider the study of the social components of pain as just another element to be very important because, together with biological and psychological elements, it helps us understand this complex, multifaceted phenomenon. The painful experience takes place in a social context that gives it meaning, acquiring meaning or negating it, for the person in pain, the health care system, and society itself. But, despite what has been set out, rarely is the social context of the person in pain analyzed or the variables that may have an incidence on its interpretation, perception, or even intensity.

\section{Conclusion}

We think that it is necessary to carry out studies on pain from a sociological point of view, which may make it possible to account for this complex phenomenon that has not been studied much and has many remaining questions yet to be answered.

The strengths of this paper include highlighting this new perspective on pain, to give voice to the suffering population, while also going beyond the psychological (and therefore individual) view, in order to pay attention to a sociological (and therefore social, cultural, and intersubjective) view, shared by society as a whole and giving meaning to pain.

The potential limitations of this research include the fact that it is not possible to compare it with other similar studies, as it is a novel study. This may make it difficult to discover whether the same results would be yielded in other geographic areas, with a different culture and social norms. It would be very interesting if researchers from other countries replicated this study, whose methodology, files, and questionnaire are freely accessible (see Materials and methods), so that the results could be corroborated and the body of knowledge increased.

\section{Acknowledgments}

This project has been made possible thanks to the funding of the Spanish Centro de Investicaciones Sociológicas (CIS), which carried out the field work, according to the commitment included in the 2016 annual tender for carrying out a survey module. This project is also included within the Project RETOS of the Spanish National Plan for Research 2013-2016 (Ref. CSO2014-55586-R). We would also like to thank everyone who selflessly collaborated by answering the questionnaire, as it would be impossible to advance in the field of social knowledge without their contribution.

\section{Author contributions}

All authors contributed toward data analysis, drafting and revising the paper, gave final approval of the version to be published and agree to be accountable for all aspects of the work. 


\section{Disclosure}

The authors report no conflicts of interest in this work.

\section{References}

1. LoeserJD, MelzackR. Pain: an overview.Lancet. 1999;353(9164):1607-1609.

2. Kirmayer LJ. Culture and the metaphoric mediation of pain. Transcult Psychiatry. 2008;45(2):318-338.

3. Boddice R. Pain. A Very Short Introduction. Oxford: Oxford University Press; 2017.

4. Jensen MP, Turner JA, Romano JM, Lawler BK. Relationship of pain-specific beliefs to chronic pain adjustment. Pain. 1994;57(3): 301-309.

5. Lavielle P, Clark P, Martínez H, Mercado F, Ryan G. Conducta del enfermo ante el dolor crónico. Salud Pública de México. 2008;50(2):147-154.

6. Saunders C, Baines M. Living With Dying: The Management of Terminal Disease. 1st ed. Vol. 74. Oxford: Oxford University Press; 1983.

7. Pain terms: a list with definitions and notes on usage. Recommended by the IASP Subcommittee on Taxonomy. Pain. 1979;6(3):249.

8. Zola IK. Culture and symptoms. An analysis of patients presenting complaints. Am Sociol Rev. 1966;31:615-630.

9. Bustos R. Elementos para una antropología del dolor: el aporte de David Le Breton [Elements for an anthropology of pain: the contribution of David Le Breton. Acta Bioethica. 2000;6(1):105-111. Spanish.

10. Le Breton D. Anthropologie de la doleur. Paris: Métailié; 1995.

11. Sánchez B. Abordajes teóricos para comprender el dolor humano. Revista Aquichan. 2003;3:32-41. Spanish.

12. Eisenberger NI, Lieberman MD. Why rejection hurts: a common neural alarm system for physical and social pain. Trends Cogn Sci. 2004;8(7):294-300.

13. Dolcos F, LaBar KS, Cabeza R. Interaction between the amygdala and the medial temporal lobe memory system predicts better memory for emotional events. Neuron. 2004;42(5):855-863.

14. Schraw G. The seven sins of memory: how the mind forgets and remembers. Educ Psychol Rev. 2003;15(1):101-113.

15. Chen Z, Williams KD, Fitness J, Newton NC. When hurt will not heal: exploring the capacity to relive social and physical pain. Psychol Sci. 2008;19(8):789-795.

16. Pradier B, Lanning K, Taljan KT, Feuille CJ, Nagy MA, Kauer JA. Persistent but labile synaptic plasticity at excitatory synapses. J Neurosci. 2018;38(25):5750-5758.

17. Flor $\mathrm{H}$. New developments in the understanding and management of persistent pain. Curr Opin Psychiatry. 2012;25(2):109-113.

18. Corter JE. Tree Models of Similarity and Association. Quantitative Applications in the Social Sciences. Thousand Oaks, CA; SAGE: Vol. 112. 1996.
19. Melzack R, Sensory CKL. Motivational and central control Determinants of Pain. A new conceptual model. In: Kenshalo D, editor. The Skin Senses. Springfield, IL: CC Thomas; 1968;423-443.

20. Astudillo W, Mendinueta C, Astudillo E, Gabilondo S. Principios básicos para el control del dolor total [Basic principles for the control of total pain]. Rev Soc Esp Dolor. 1998;6:29-40.

21. Biedma Velázquez L, García de Diego JM, Serrano del Rosal R. Análisis de la no elección de la analgesia epidural durante el trabajo de parto en las mujeres andaluzas: "la buena sufridora" [Analysis of rejection of epidural analgesia during labor in Andalusian women: "the silent sufferer"]. Revista de la Sociedad Española del Dolor. 2010;17(1):3-15. Spanish.

22. Moscoso J. Pain: A Cultural History. Basingstoke: Palgrave, McMillan; 2012.

23. Baszenger I. Inventing Pain Medicine. From the Laboratory to the Clinic. Londres: Rutgers; 1998.

24. Morris D. The Culture of Pain. Berkeley: University of California Press; 1991.

25. Bourdieu P. Capital symbolique et classes sociales. L'Arc. 1978;72: 13-19.

26. Cooper AE, Corrigan PW, Watson AC. Mental illness stigma and care seeking. J Nerv Ment Dis. 2003;191(5):339-341.

27. Stuart H, Arboleda-Flórez J, Sartorius N. Paradigms Lost. Fight Stigma and the Lessons Learned. New York: Oxford University Press, Inc; 2012:3-19.

28. Lejarraga A. La construcción social de la enfermedad. Arch argent pediatr. 2004;102(4):271-276. Spanish.

29. Miller C, Newton SE. Pain perception and expression: the influence of gender, personal self-efficacy, and lifespan socialization. Pain Manag Nurs. 2006;7(4):148-152.

30. Grande-García I. Neurociencia social: El maridaje entre la psicología social y las neurociencias cognitivas. Revisión e introducción a una nueva disciplina. Anales de psicología. 2009;25(1):1-20. Spanish.

31. Young SN, Moskowitz DS. Foundations in Social Neuroscience. $J$ Psychiatry Neurosci. 2003;28(5):375-376.

32. Harmon-Jones E, Winkielman PA. Brief overview of social neuroscience. In: Harmon-Jones E, Winkielman P, editors. Social Neuroscience: Integrating Biological and Psychological Explanations of Social Behavior. New York: The Guilford Press; 2007:3-11.

33. Centro de Investigaciones Sociológicas. 3137/Percepciones Sociales del Dolor. CIS; 2016. Available from: http://www.cis.es/cis/opencm/ EN/2_bancodatos/estudios/ver.jsp?\&estudio=14290. Accessed November 9, 2018. Spanish. 


\section{Supplementary material}

Table SI Questionnaire questions (the complete questionnaire is available at: http://www.cis.es/cis/opencm/EN/2 bancodatos/ estudios/ver.jsp?\&estudio=|4290)

\begin{tabular}{|c|c|}
\hline Questions & Response options \\
\hline $\begin{array}{l}\text { Q.7 As you know, everyone throughout their life suffers some } \\
\text { kind of pain, which may be physical, psychological, emotional, } \\
\text { or other types of pain. Tell me if you have ever suffered any } \\
\text { of the types of pain that I am going to tell you. (MULTIPLE } \\
\text { CHOICE. READ ONE BY ONE AND CHECK THE ONE(S) } \\
\text { SELECTED). }\end{array}$ & $\begin{array}{l}\text { - Bone or muscle pain } \\
\text { - Headache, earache, eye pain, or toothache } \\
\text { - Stomachache, digestive distress, liver, or kidney pain } \\
\text { - Pain caused by anxiety, depression, or stress } \\
\text { - Pain caused by tiredness for no apparent reason } \\
\text { - Pain caused by a continuing feeling of anguish }\end{array}$ \\
\hline $\begin{array}{l}\text { Q.9 Currently, are you suffering any of the pains that I am } \\
\text { about to mention? (MULTIPLE CHOICE. READ ONE BY } \\
\text { ONE AND CHECK THE ONE(S) SELECTED). }\end{array}$ & $\begin{array}{l}\text { - Pain caused by heartbreak or breakup } \\
\text { - Pain caused by the death of a loved one } \\
\text { - Pain caused by an important betrayal or deception }\end{array}$ \\
\hline $\begin{array}{l}\text { Q.10 Out of the pains that you have stated that you have } \\
\text { suffered or are currently suffering, which one would you say } \\
\text { that is more relevant? Which one do you remember most } \\
\text { vividly? }\end{array}$ & $\begin{array}{l}\text { - Another kind of pain that you consider important, which one? } \\
\text { - (DO NOT READ) None } \\
\text { - Does not remember } \\
\text { - Does not answer }\end{array}$ \\
\hline $\begin{array}{l}\text { Q.23 In your opinion, which is the worst pain that may be } \\
\text { suffered? (ONLY ONE ANSWER) }\end{array}$ & $\begin{array}{l}\text { - } \text { Bone or muscle pain } \\
\text { - Headache, earache, eye pain, or toothache } \\
\text { - Stomachache, digestive distress, liver, or kidney pain } \\
\text { - Pain caused by anxiety, depression, or stress } \\
\text { - Pain caused by tiredness for no apparent reason } \\
\text { - Pain caused by a continuing feeling of anguish } \\
\text { - Pain caused by heartbreak or breakup } \\
\text { - Pain caused by the death of a loved one } \\
\text { - Pain caused by an important betrayal or deception } \\
\text { - Another kind of pain that you consider important, which one? } \\
\text { - (DO NOT READ) None } \\
\text { - Does not remember } \\
\text { - Does not answer }\end{array}$ \\
\hline
\end{tabular}

Journal of Pain Research

\section{Publish your work in this journal}

The Journal of Pain Research is an international, peer reviewed, open access, online journal that welcomes laboratory and clinical findings in the fields of pain research and the prevention and management of pain. Original research, reviews, symposium reports, hypothesis formation and commentaries are all considered for publication.

\section{Dovepress}

The manuscript management system is completely online and includes a very quick and fair peer-review system, which is all easy to use. Visit http://www.dovepress.com/testimonials.php to read real quotes from published authors. 